\title{
Elizabeth Kridl Valkenier and the World of Russian Art
}

\author{
RONALD MEYER
}

In his review of the "dismal show" of "Russian and Soviet Painting" mounted at the Metropolitan Museum of Art (1977-1978), Hilton Kramer, the lead art critic at the New York Times, bemoans the poor quality of the exhibits, but is even more outraged at the museum offering nothing to counterbalance the standard Soviet ideological interpretations: "From neither the catalog nor the wall labels in the exhibition, moreover, can we expect to be told anything but the official Soviet line."1 Kramer recommends an antidote to the Met's ideological pandering:

\footnotetext{
Fortunately, there is a new book at hand-Elizabeth Valkenier's Russian Realist Art (Ardis)-that fits the need for a serious and candid study of the political history of Russian art from the 1860s to the present. ... Her work has the great merit of providing us with a detailed account of the politics and ideology that have dominated so much of the art we see in this exhibition.... Hers is by no means the last word on the subject, but it is in many respects a useful first word, and it arrives just in time to act as a corrective to the Met's sunny embrace of this human tragedy. ${ }^{2}$
}

First, it is interesting that rather than choose some standard history, Kramer promotes a first book by a relatively unknown author, published by a fledgling independent small press in Michigan with no track record as a publisher of books on art. But what is more interesting, and which perhaps explains my first point, is that Kramer appreciates Valkenier's "first word," how she connects the rise and fall of Russian realist art from the "initial creative phase of Peredvizhnichestvo," to its "tendentious rehabilitation" under Stalin. ${ }^{3}$ And more important, how Valkenier challenges the prevailing view both in the Soviet Union and in the West, as exemplified by the Metropolitan Museum's show, through her analysis as a historian of the "nexus between society, politics and art."

Interviews conducted in the 1970s with both the conservative and liberal camps of art historians and curators, undertaken in tandem with archival research, laid the groundwork for Valkenier's pioneering study. Fortunately, Valkenier was not a novice researcher in the USSR - the gloom of the Cold War atmosphere did nothing to facilitate access to archives and scholars. As she writes in her essay "The Totalitarian Model and Me," her initial contacts and experiences in the USSR date back to a ten-day Intourist trip to Moscow in 1958, from which she brought back the impression that "Soviet citizens were not conforming to the totalitarian model." 4 The following year she returned to Russia as a guide for the book section of the first American Exhibit, which reinforced her impressions that ordinary citizens, unlike the monolithic mass of true believers portrayed by Cold War ideologues, had independent opinions and hungered for information about the West from which they had been cut off for half a century. When Valkenier returned to Moscow in 1967, it was in the capacity of research assistant of Philip Mosely, a foreign policy scholar-Valkenier had followed Mosely from the Council on Foreign Relations, where he held the post of director of studies, to Columbia University, where Mosely had been named director of the European Institute. ${ }^{5}$ Her careful reading as Mosely's assistant of the literature on Soviet foreign policy in the third world led her to believe that there were "disagreements over the old orthodoxies" and evolving new interpretations. Her research plan was to spend a month interviewing "Soviet specialists whose arguments [on foreign policy] represented the 'new thinking' of those days." With Mosely's introductions she met highly placed Soviet experts with whom she maintained contact for the next thirty years, which yielded a number of articles and ultimately her second book, The Soviet Union and the Third World: An Economic Bind (Praeger, 1983 and 1985). Valkenier's work in this field pointed to the economic difficulties in the ambitious Soviet aid policies-an argument that diverged from the prevalent belief in Moscow's successes in the developing countries. 
Questioning received opinion would continue to be Valkenier's modus operandi on her art history research trips to the USSR and Russia, funded by the Russian and Harriman Institutes, IREX, the Pew Foundation, and the National Council for Soviet and East European Research. It is characteristic of Valkenier's approach that she enlisted both the conservatives, many of whom held influential positions in the Soviet Academy of Arts and arts administrations, and the liberals, who were more likely to be found at universities and on museum staffs and were suggesting new approaches outside of the official framework. She found both groups eager to influence how she would frame her story. The conservatives provided her with their publications of documents, letters, and the like, which reinforced the official-highly politicized-version of history. On the other hand, the liberals prompted her to see that "the Peredvizhniks' traveling exhibits from 1871 on were motivated as much by a shrewd gamble to tap the market among the new middle class as by the proclaimed desire of the intelligentsia 'to serve the people," 6 and that many of the Peredvizhniki who left the Academy in the 1870 s in protest against the stultified official ways rejoined that tsarist institution some twenty years later.

Two scholars of the liberal camp, Ilia Zilbershtein, editor of the scholarly book series Literaturnoe nasledstvo (Literary Heritage), and Sofia Goldshtein, archivist at the Tretiakov Gallery, facilitated Valkenier's access to the papers of the State Committee on Art, established in 1936, "as a political watchdog and command center for the Stalinization of the field." Under the supervision of the Committee, Repin became the equal of Rembrandt, and nonrealist works were banished to the storage bins. Needless to say, having the Committee's minutes and protocols helped Valkenier paint a very different picture of the posthumous reception and reputation of the Peredvizhniki. An interesting footnote to Valkenier's study of the State Committee on Art's archive is that a decade later, when she was working on her book on Repin, she was denied access to this particular archive. She also discovered that her first book was not available on open shelves in the libraries.

Valkenier's three decades of research on art history in the Soviet Union and Russia would bear fruit as her three books: Russian Realist Art, based on her doctoral dissertation (Columbia University, PhD 1973, History), but considerably revised and expanded to go beyond the Peredvizhniks' heyday and trace their influence into the twentieth century as a model for socialist realism;
Ilya Repin and the World of Russian Art (Columbia University Press, 1990), which is not simply a biography of the foremost Peredvizhnik but also an insightful look at the distorting lens of Soviet historiography; and finally, Valentin Serov: Portraits of Russia's Silver Age (Northwestern University Press, 2001), a study of Repin's best-known pupil set against the background of the transition from realism to Russian modernism and the interplay of art and social history during Russia's Silver Age. These lines from Valkenier's introduction to her book on Serov might be applied to her art history works as a whole:

Painting prominent people of the day in business, government, society, and the arts, [Serov] provides a gallery of important figures in Russia's Silver Age.... Serov's penetrating "reading" of the lives and circumstances of his sitters gives us a far more varied and intricate group portrait of the epoch than is customarily presented in Russian or Western historiography. The visual thus richly extends and amplifies the usual sources, political or literary.

There is much more to be said about Elizabeth Valkenier's contributions to the study of Russian art, at the very least that she edited the catalogue of The Wanderers for the exhibition from the Soviet Union mounted at the Dallas Museum of Art in 1991, with contributions from both Russian and American scholars-surely a recognition of her status as one of the leading experts in the field. More recently, Valkenier, together with Wendy Salmond, was guest editor of a special issue of Experiment: A Journal of Russian Culture: "Russian Realist Painting. The Peredvizhniki: An Anthology" (2008), a compilation of documents (for example, letters, miscellaneous writings, and official papers) in English translation. This anthology has become not only an essential reference work for scholars, but also an invaluable teaching resource that enables art historians who do not specialize in Russia to include the Russian dimension in broader courses on realist art.

E L I Z A B E T H K R I D L, daughter of Manfred Kridl, a well-known scholar and professor of Polish Literature at Wilno University and leading proponent of Polish integralism (the Polish variant of Russian formalism or Czech structuralism), came to the United States in 1941 with her mother and brother, to join her father who had left Poland and was now teaching at Smith College. Kridl had left the University of Wilno, where he had been both 
dean of humanities and deputy pro-rector, shortly after the outbreak of World War II, when Polish personnel at the university were being relieved of their positions by the new Lithuanian Soviet government. Founder of Wilno's Social Democratic Club, Kridl opposed authoritarianism on both the left and the right. A photograph from 1936 shows the popular professor presiding over a picnic with a group of university students who included Czeslaw Milosz among their number. ${ }^{7}$ Milosz was not a student of Kridl's per se, but the professor was a steadfast supporter of the young poet from their early days together in Poland and during their joint emigration in the United States. Valkenier's most recent publication is "Way Back in Wilno ...," a memoir of her acquaintance with Milosz. ${ }^{8}$ Though she made a conscious choice not to specialize in Polish history, mainly to avoid intellectual parochialism, Valkenier wrote several important articles on the Sovietization of Polish history after World War II. As was the case with her work on art and Soviet foreign policy, careful research was supported by personal interviews, all of which served to draw attention to politicized falsification.

Kridl left Smith College in 1948, the same year that Elizabeth graduated from the college, for Columbia University, where he held the Adam Mickiewicz chair until his retirement in 1955. Elizabeth went to Yale University and earned her M.A. in history (1949). It was at Yale that she discovered her love for Russian history while taking a seminar with George Vernadsky. And it was at Yale that Elizabeth met her future husband Robert Valkenier. They moved to New York City, where Elizabeth pursued her study of Russian history-the seminar in medieval Russia with Michael Cherniavsky led to her choosing a topic in art history for her dissertation-and earned the Certificate of the Russian Institute in 1951. Robbie was longtime editor at the Council on Foreign Relations, and the editor of all of Elizabeth's work until his death in 2003. Their home on Morningside Drive in New York and their rural getaway in Connecticut have hosted friends and colleagues from the United States and abroad for countless dinners, where the very good food is always bettered by the exciting conversation and camaraderie. I count myself a very lucky beneficiary of the Valkeniers' generosity.

The present volume not only is testament to the influence of Elizabeth Valkenier's scholarly work and professional life, but also represents a tribute from colleagues, students, and friends, some of whom go back two or three decades, while others are fairly recent. It is no exaggeration to say that her extraordinary life and gift for friendship have helped shape her remarkable studies of the world of Russian art.
Publications by Elizabeth Kridl Valkenier Art History Books

Russian Realist Art. The State and Society: The Peredvizhniki and Their Tradition (Ann Arbor: Ardis, 1977; New York: Columbia University Press, 1989).

Ilya Repin and the World of Russian Art (New York: Columbia University Press, 1990).

The Wanderers. Masters of 19th-Century Russian Painting, exh. cat. (Dallas: University of Texas Press, 1991). Editor and contributor.

Valentin Serov. Portraits of Russia's Silver Age (Evanston, IL: Northwestern University Press, 2001).

"Russian Realist Painting. The Peredvizhniki: An Anthology," special issue, Experiment: A Journal of Russian Culture 14 (2008). Coedited with Wendy Salmond.

\section{Art History Book Chapters and Articles}

"The Peredvizhniki and the Spirit of the 1860s," The Russian Review 34, no. 3 (July 1975): 247-65.

"Politics in Russian Art: The Case of Repin," The Russian Review 37, no. 1 (January 1978): 14-29.

"Repin's Search for the Revolutionary's Image in 'They did not expect him," Gazette des Beaux-Arts 91 (May-June 1978): 207-13.

“La Tentation par Ilya Repin (1844-1930)," La Revue du Louvre 2 (April 1981): 131-33.

"The Intelligentsia and Art," in Art and Culture in Nineteenth-Century Russia, ed. Theofanis George Stavrou (Bloomington: Indiana University Press, 1983), 152-72.

"Ilya Repin and David Burliuk," Canadian-AmericanSlavic Studies (Spring-Summer 1986): 55-62.

"The Art of the Wanderers in the Culture of Their Time," in The Wanderers: Masters of 19th-Century Russian Painting, ed. Elizabeth K. Valkenier (Dallas: University of Texas Press, 1991), 1-23.

“The Writer as Artist's Model: Repin's Portrait of Garshin," The Metropolitan Museum of Art Journal 28 (1993): 207-16.

"Repin za rubezhom [Repin Abroad]," Nashe nasledie [Our Heritage] 6, no. 31 (1994): 41-49.

"The Birth of a National Style," in The Russian Stravinsky, ed. Joseph Horowitz (New York: Brooklyn Academy of Music, 1994), 24-32.

"Repin in Emigration," The Harriman Review 8, no. 4 (December 1995): 41-50.

"Opening up to Europe: The Peredvizhniki and the 
Miriskussniki Respond to the West," in Russian Art and the West: A Century of Dialogue in Painting, Architecture and the Decorative Arts, ed. R.P. Blakesley and S.E. Reid (DeKalb: Northern Illinois University Press, 2006), 45-60.

"Repin and His Critics", in Critical Exchange: Art Criticism of the Eighteenth and Nineteenth Centuries in Russia and Western Europe, ed. C. Adlam and J. Simpson (Oxford and New York: Peter Lang, 2009), 227-41.

\section{Other Art Publications}

Introduction and Catalogue, Exhibition of Soviet World War II Posters (The Russian Institute, Columbia University, 1976).

Reviews of the exhibition of Russian and Soviet art at the Metropolitan Museum of Art in the Christian Science Monitor (18 April 1977) and the Village Voice (25 April 1977).

"An Unknown War" (The Lewis Cowan Collection of Soviet World War II Posters), Columbia Library Columns 29, no. 1 (November 1979): 197-213.

Entries on Russian art and architecture in Academic American Encyclopedia (Princeton: Arete, 1981, 1993).

"The Birth of Realism" and "The Move toward Decorativism," The Cambridge Encyclopedia of Russia and the Soviet Union (Cambridge: Cambridge University Press, 1982, 1993).

Entries on nineteenth-century Russian painters in The Dictionary of Art (New York: Macmillan, 1995).

Entry on Russian art and architecture in Collier's Encyclopedia (New York, 1995).

\section{Selected Soviet/Russian Foreign Policy Publications}

"Recent Trends in Soviet Research on the Developing Countries," World Politics 20, no. 4 (July 1968); reprinted in W.R. Duncan, ed., Soviet Policy in Developing Countries (Waltham, MA: Ginn-Blaisdell, 1970).

"The USSR, the Third World, and the Global Economy," Problems of Communism (July-August 1979).

The Soviet Union and the Third World: An Economic Bind (New York: Praeger, 1983 and 1985).

"East-West Economic Competition in the Third World," in East-West Tensions in the Third World, ed. Marshall D. Shulman (New York: W.W. Norton, 1986).
"Glasnost' and Perestroika in Soviet-Third World Economic Relations," The Harriman Institute Forum (October 1991).

"Russian Policies in Central Asia: Change or Continuity?" SAIS Review (June 1994).

"The Collapse of the Soviet Union and the Future of the Socialist Model," in Russia and the Third World in the Post-Soviet Era, ed. M.S. Mesbahi (Gainesville, FL: University Press of Florida, 1994).

\section{Historiography Publications}

"The Rise and Decline of Official Marxist History in Poland, 1945-1983," Slavic Review 44, no. 4 (Winter 1985).

"Teaching History in Post-Communist Russia," The Harriman Institute Forum (April 1991).

"Stalinizing Polish History: What Soviet Archives Disclose," East European Politics and Society 7, no. 1 (Winter 1993).

"The Changing Face of Oriental Studies in Russia," Central Asia Monitor (April 1994).

Notes

1. Hilton Kramer, "Détente Yields a Dismal Show" (Art View), New York Times (24 April 1977).

2. Kramer, "Détente Yields a Dismal Show."

3. Elizabeth K. Valkenier, Russian Realist Art. The State and Society: The Peredvizhniki and Their Tradition (Ann Arbor: Ardis Publishers, 1977; reprinted by Columbia University Press, 1989), xv-xvi.

4. "The Totalitarian Model and Me," The Harriman Review 14, nos. 1-2 (November 2002): 1622; <http://www.harrimaninstitute.org/MEDIA/01277. pdf $>$ (accessed 7 November 2011).

5. See Valkenier's appreciation of her mentor, "Philip Edward Mosely," The Harriman Institute, 1946-2006 (New York: Harriman Institute, Columbia University, 2006), 22-25.

6. Valkenier, "Philip Edward Mosely," 19.

7. This photograph is reproduced in The Harriman Institute 1946-2006, 40. Milosz stands behind Kridl making a funny gesture with his hands; Elizabeth Kridl is sitting third from the right-she and her brother are the youngest members on this picnic outing. 8. "Way Back in Wilno ...," An Invisible Rope: Portraits of Czeslaw Milosz, ed. Cynthia L. Haven (Athens: Ohio University Press, 2011), 10-15. 